\title{
Factors Affecting the Adoption of Moodle in Gulf Universities
}

\author{
Abdulsadek Hassan Abdulsadek, Ismail Noori Mseer, Allam Hamdan, Muneer Al Mubarak, \\ Adel M. Sarea
}

\begin{abstract}
The study examined the Moodle system adoption by the students in three Gulf universities "Saudi Arabia, United Arab Emirates and the Kingdom of Bahrain" and examines the students' perceptions towards this system from the framework of two theories: The Theory of Reasoned Action (TRA) and the Theory of Planned Behavior (TPB). This study is descriptive survey research. The convenience sampling technique was adopted in the selection of 231 respondents from the sampled universities. The results revealed that the students used the Moodle system for many purposes such as doing assignments, to check upcoming events, downloading the course materials and to participate in discussions with my instructors. The results also revealed that the most impactful perceived ease of use factors: easy usage, flexibility and interaction. Finally, the study is suggested to investigate academic concerns and needs to develop the usage of Moodle in Arabian and Gulf universities.

Keywords: Adoption of Moodle in Mass Communication, Gulf Universities, Education
\end{abstract}

\section{INTRODUCTION}

The fast growth of Information and communication technology (ICT) has influenced all aspects of contemporary life, including education that have affected by this technology. E- Learning has become widely one of the educational systems beside the traditional structure education. E- Learning is a teaching process that takes place in the Internet environment making this process more interactive and collaborative between the instructor and his students. In this process, the knowledge is stored and updated regularly by the faculty members who follow the evolution of this process and monitor student performance in the tasks assign to them. The word "Moodle" is an acronym for "Modular object- oriented dynamic learning environment", the Moodle system begun as a research of PHD by Australian Martin Dougiamas in 1999 to help educator to study at effective collaborative on - line learning community (1).

Revised Manuscript Received on December 30, 2019.

* Correspondence Author

Dr Abdulsadek Hassan Abdulsadek, Assciate Professor- Mass Communication and Public Relations Department, Ahlia University, Manama, Bahrain.

Professor Ismail Noori Mseer, Acting Dean, College of Arts \& Science

- Arabic \& General Studies Department, Ahlia University, Manama, Bahrain.

Professor Allam Hamdan, Acting Dean Accounting \& Economics Dept. College of Business \& Finance. Ahlia University, Manama, Bahrain.

Dr. Muneer Al Mubarak, Associate Professor, Acting VP for Admin \& Finance/ Acting Dean of Student Affairs. Ahlia University. Manama, Bahrain.

Dr. Adel Mohammed Yaslam Sarea, Associate Professor. College of Business \& Finance - Accounting \& Economics Dept, Ahlia University, Manama, Bahrain.

(c) The Authors. Published by Blue Eyes Intelligence Engineering and Sciences Publication (BEIESP). This is an open access article under the CC BY-NC-ND license (http://creativecommons.org/licenses/by-nc-nd/4.0/)
Education has been greatly affected by the integration of modern technologies such as online leaning "Moodle" that makes learning more flexibility and accessibility and can positively affect learner satisfaction and performance and support traditional classroom system.

The universities - all around the world - have adopted ELearning system as a tool of curriculum teaching staff development and student's performance by effective use of technologies that facilities the educational process and move it forward. This process enables staff members to provide their students with all materials belong the different courses not located in the same place and they can evaluate the learning process.

The universities in the Middle East- especially in Gulf areahave introduced the Moodle system in E- learning to improve the quality of learning and teaching. The universities have encouraged their students to use this system. However, the traditional method of teaching and learning is still preferred. Mass Communication education requires a variety of materials; educational, physical, graphical and actual information. The traditional Mass Communication education includes the use of texts, images, lectures and books. This old style of Mass Communication education is reinforced through blending E-learning strategies that are essential in the field of Mass Communication education especially in practical courses because of the development in software programs and Radio and Television production techniques.

In Gulf area, universities have recently adopted the Moodle system as the traditional teaching process was changed after using Information and multimedia technology as a new method of teaching, at the same time, the learning environment was also changed by using electronic media. In spite of this, there are many barriers still face E- learning successful application where this system is still in its infancy phrase.

Consequently , this study investigates Moodle system adoption by the students in three gulf universities "Saudi Arabia , United Arab Emirates and Kingdom of Bahrain" and examines the students perceptions towards this system from the framework of two theories : The Theory of Reasoned Action (TRA) and the Theory of Planned behavior (TPB).

Problem Statement:

The use of Moodle has become widely spread in many educational tertiaries because of core benefits to improve the quality of education and to reinforce learning and teaching process, regarding the correct application to increase students' participation in the learning process and enhanced the learning outcomes. 
The usage of Moodle system has several benefits: sharing of knowledge among students, improving courses content, providing a greater number of resources, enhancing the quality of learning and teaching, creating attractive activities, encouraging the effective communication and interactions between instructor and students and promoting students' performance and outcomes.

In spite of wide use of Moodle in many Mass Communication colleges and departments in Gulf area, there are no studies to examine the efficiency and usability of Moodle in these colleges, the common issue is how to integrate this system with traditional system where many faculty members are not trained or have little skills to deal with this system.

Regarding the lack of information about the usage of Moodle in Gulf universities especially Mass Communication colleges, the researcher conducted this study to carry out to focus on the nature of this usage and all factors affected it. Study significant:

- The study is significant because it explored one the educational issues in Gulf area by focusing on the adoption of Moodle in Mass Communication colleges.

- The role of Moodle in Mass Communication colleges and departments has not been widely studied in Gulf area. This study provided a comprehensive understanding of ELearning process in Gulf universities, applying to Mass Communication colleges.

- The study is significant for higher Education tertiaries in Gulf area to achieve their mission, visions and goals in improving the nature of educational process depending on new technologies "Moodle" in teaching and learning in Mass Communication colleges.

- The study examines the hypotheses of two theories: The Theory of Reasoned Action (TRA) and the Theory of Planned behavior (TPB) in Gulf universities as they are the best theories to explore the adoption of Moodle in in Mass Communication colleges.

Theoretical Background:

The Theory of Reasoned Action (TRA):

Fishbein and agzen introduced the origin of this Moodle in Social physiology in 1975 that explained and predicted individual behavior.

The Main Hypothesis of The Theory of Reasoned Action (TRA):

The main hypothesis of the theory of reasoned action (TRA) is individual is rational and will use information to make systematic decisions. This theory considered the main predictor of behavior is behavioral intention, while the individual's attitude towards the behavior influences the intention (2).

Intention is a belief that is conceived by an individual before taking a decision. Thus, Behavioral intention determines actual behavior besides two variables: attitudes (Negative or Positive evaluation of performing behavior) and subjective norms (perceived influences that others may have) (3). In general, the increase of attitudes and subjective norms leads to strong intention to perform the behavior (4). An individual will do certain behavior when he evaluates it positively. Thus, attitude is an individual belief of his behavior outcome (negative or positive). Finally, attitudes have a significant effect on behavioral intention (5).

Some studies indicated there is a significant between males and females in favor of females in behavioral intentions and also trust determine behavioral intentions in favor of females too (Abdulwahab Ali Almarazro\&et al, 2018) (6).
The Theory of Planned behavior (TPB):

Fishbein and agzen introduced the origin of this Moodle 1975. This model is based on individuals perceived behavior as positive; they will more active to do the behavior. This model explains the intention of hard people and its role in performing the behavior. This behavior is influenced by attitude, subjective norms and perceived behavior, these factors have a significant predict of intention. This model explains the role of intentions in changing individuals' behavior (7).

This model is similar with (TRA), but the difference is that it focuses on perceived behavioral control which refers to the perception control of the performance of a certain behavior (8).

The factors of (TPB):

Attitude: refers to outcome evaluation (positive or negative), the attitude has a significant role on the behavior of the user to accept or to use the technology (8).

Perceived behavioral control: refers to the individuals' engagement in behavior that feel and they have control over and at the same time they avoid the behavior that they don't control over, as a consequence, the perceived behavioral control can predict the intention to use technology(10).

Self- efficacy: refers to the tools availability to achieve the tasks have a significant role in accepting the new technology. There are three factors influence the self-efficacy: user's knowledge, experience and expertise (11).

Perceived Ease of use: perceived ease of use has a significant role in accepting a new technology, perceived ease of use refers to the individuals' perception towards the adoption of new technology according to perceived ease of use (12).

Literature Review:

Numerous studies have been directed towards the adoption of Moodle in leaning and teaching in educational institutions .These studies showed that the Moodle systems allows better co- operation between instructor and students and makes teaching and learning more easily through saving teaching materials on the Moodle system and download materials (Dharmendra Chourishi \& et al.2011)(13). The Moodle system provides interactivity also between instructor and students by using interactive tools to facilitate the good communication such as: Chats, assignments submission, Forums, online news and announcements, files downloads grading /marks, and online quiz (Carolina Costa \& et al.2012) (14). Moodle produces some benefits for students like: Availability, less technical difficulties, continuous progress, flexibility, and most accepted by top universities all over the world (Prashant Bargea, B.R. Londhe, 2014) (15). The Moodle also provides other benefits such as: getting courses and topics, collaborating with peers in doing homework, facilitating the learning method, facilitate the self-assignments and online assessment is more objective than traditional method "Face-to- Face" learning (Gabriela Carmen Oproiu, 2015)(16) , introducing the course content, course specification and course feedback (Deepak KC,2017) (17). the most used information materials in the Moodle are texts and images (Nurkhamimi Zainuddin,2016) (18).

In other side, some instructors viewed that the online method of learning must combine with traditional learning (Irina Rymanova, 2015) (19).

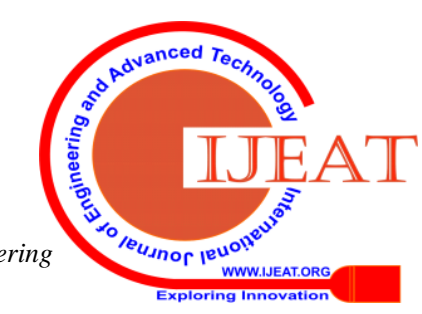


Other studies showed that in higher education institutions, there is an essential need to use Information Communication Technologies (ICT) to cope with new trends and challenges in education and commit to E- learning education. The perception of the ease of use of Moodle is significantly influenced by technology complexity and trialability (Teo, Timothy \& et al, 2019)(20). while Behavioral intentions has a significant influence of Moodle usage (Olayemi Abdullateef Aliyu\&et al,2019)(21) .From the side of students, the studies indicated that the students must be core focus in the adoption of technology and the instructors must take part in developing teaching and learning by using Moodle system (Valentino van de Heyde\& André Siebrits, 2019)(22), the knowledge sharing and quality have a significant role among students on E-learning acceptance, at the same time, innovativeness and trust have no significant role among students on E-learning acceptance (Salloum, Said A\&et al, 2019)(23). The innovativeness is influenced by the technology acceptance of teachers and perceived ease of use , perceived usefulness and subjective norms determine the behavioral intentions (Sacide Güzin Mazman Akar,2019)(24).The adoption of E- learning has also a good influence in academic performance so the students must have good skills to perform the academic assignments and must be active in learning process through effective engagement that support cognitive and noncognitive for academic performance in the universities (Hye Jeong Kim\&et al,2019)(25).In general, the students indicated Moodle system effectiveness and efficiency made them more satisfied with the Moodle system available at universities(26).

\section{OBJECTIVES}

- To establish the relationship between variables to determine the current usage and attitude towards Moodle system among mass Communication students in Gulf universities.

- To determine the factors of (TRA) and (TPB) influence the Moodle system among mass Communication students in Gulf universities.

- To explore the influence of other factors: Technical support, Communication and Perceived Satisfaction that affect the use of Moodle system among mass Communication students in Gulf universities.

Questions:

- What is the frequency of Moodle system usage among mass Communication students in Gulf universities?

- What are the purposes of Moodle system usage among mass Communication students in Gulf universities?

- What are the factors of (TRA) and (TPB) that influence the Moodle system among mass Communication students in Gulf universities?

- What is the influence of other factors: Technical support, Communication and Perceived Satisfaction that affect the use of Moodle system among mass Communication students in Gulf universities?

Hypotheses:

- There is a significant correlation between perceived ease of use of Moodle system and perceived usefulness among mass Communication students in Gulf universities.

- There is a significant correlation between perceived ease of use of Moodle system and students 'attitude towards Moodle system usage among mass Communication students in Gulf universities.
- There is a significant correlation between perceived usefulness and attitudes towards Moodle system usage among mass Communication students in Gulf universities.

- There is a significant correlation between perceived usefulness of use of Moodle system and behavioral intention among mass Communication students in Gulf universities.

- There is a significant correlation between perceived usefulness of use of Moodle system and Self- efficiency among mass Communication students in Gulf universities.

- There is a significant correlation between Subjective Norms and attitudes towards Moodle system usage among mass Communication students in Gulf universities.

\section{METHOD AND MATERIALS}

\section{Population:}

The study population consists of all students used Moodle system in Gulf universities "Saudi Arabia, United Arab Emirates and Kingdom of Bahrain" at the second semester of the academic year 2018-2019.

\section{Sample:}

Sample is defined as the subset of the population selected to participate in the study to represent the target population (27). Using a convenience sampling technique, the participants consist of 231 undergraduate students who are available for and willing to participate in the study (28).

Table (1) The demographic characteristics of respondents

\begin{tabular}{|c|c|c|c|}
\hline \multirow{2}{*}{$\begin{array}{l}\text { The } \\
\text { Variable }\end{array}$} & \multirow{2}{*}{ Categories } & \multicolumn{2}{|l|}{$\mathrm{N}=231$} \\
\hline & & Number & Percentage \\
\hline \multirow[t]{2}{*}{ Gender } & Male & 132 & 57.14 \\
\hline & Female & 99 & 42.86 \\
\hline \multirow{2}{*}{$\begin{array}{l}\text { Type of } \\
\text { university }\end{array}$} & governmental & 91 & 39.39 \\
\hline & private & 140 & 60.61 \\
\hline \multirow[t]{3}{*}{$\begin{array}{l}\text { Moodle } \\
\text { experience }\end{array}$} & $\begin{array}{l}\text { Less than } 6 \\
\text { months }\end{array}$ & 22 & 9.52 \\
\hline & $\begin{array}{lll}\text { From } & 6 \\
\text { months to } & 1 \\
\text { years } & & \\
\end{array}$ & 88 & 38.10 \\
\hline & $\begin{array}{l}\text { One year and } \\
\text { more }\end{array}$ & 121 & 52.38 \\
\hline \multirow[t]{3}{*}{ Age } & $\begin{array}{l}\text { Less than } 20 \\
\text { years }\end{array}$ & 108 & 46.75 \\
\hline & $\begin{array}{ll}\text { From } & 20 \\
\text { years to } 22 \\
\text { years }\end{array}$ & 98 & 42.42 \\
\hline & $\begin{array}{l}22 \text { years and } \\
\text { more }\end{array}$ & 25 & 10.82 \\
\hline
\end{tabular}

Of the 231 respondents who answered gender question, slightly more than half of the respondents were males constituting 57.14\% ( $\mathrm{N}=132)$, while women constituting $42.86 \%(\mathrm{~N}=99)$ of the total respondents. With regard the type of university, the majority of respondents were from private universities that contributes $60.61 \%(\mathrm{~N}=140)$ of total respondents while governmental universities only contribute 39.39\% ( $\mathrm{N}=91)$. Regarding the Moodle experience among Mass Communication students, the majority of students came from one year and more 52.38\% ( $\mathrm{N}=121)$, followed by from 6 months to 1 years $38.10 \%(\mathrm{~N}=88)$ and $9.52 \%(\mathrm{~N}=22)$ are experienced Less than 6 months. 
Lastly, the results revealed that the majority of respondents came from age group Less than 20 years old $46.75 \%$ $(\mathrm{N}=108)$, followed by age group from 20 years to 22 years $42.42 \%(\mathrm{~N}=98)$ and $10.82 \%(\mathrm{~N}=25)$ are aged 22 years and more.

\section{QUESTIONNAIRE}

The study used online questionnaire by using google drive application to avoid respondents' fatigue because the paper-based questionnaire could lead to a less response (29), more time and more funding (30). The questionnaire applied to students had 14 items most of them closed items. The students were from different Mass Communication colleges and departments namely Moodle system. The questionnaire included questions in three categories: The first category included characterization of the participants "demographic information" in terms: gender, Moodle experience, type of universities and age. The second category included characterization of the general use of Moodle activities in terms: frequency of usage, purpose of use and attitudes toward Moodle system. The third category included characterization of Reasoned Action and planned behavior of the Moodle system and its obstacles in Gulf universities. A three- point Likert scale was used which ranging from 1 for (agree) to 3 (disagree) to measure each study items

The questionnaire was done in English language. It was translated into Arabic language and distributed in various students from colleges that offer Mass Communication as a discipline.

\section{DATA ANALYSIS}

To analyze the collected data, descriptive statistics were used to calculate the frequencies, percentage, mean standard deviation and Pearson using SPSS 23 version.

\section{RESULTS}

Table (2)

Frequency of Moodle usage by students in Gulf university

\begin{tabular}{|l|l|l|}
\hline $\begin{array}{l}\text { Frequency of } \\
\text { Moodle usage }\end{array}$ & $\mathrm{F}$ & $\%$ \\
\hline Always (100\%) & 101 & 43.72 \\
\hline Often (75\%) & 77 & 33.33 \\
\hline Sometimes (50\%) & 35 & 15.15 \\
\hline Rarely (25\%) & 18 & 7.79 \\
\hline Total & 231 & 100 \\
\hline
\end{tabular}

Table (2) shows the frequency of Moodle usage by students in Gulf university (always, often, sometimes and rarely). Most of students reported that they used Moodle always $43.72 \%(\mathrm{~N}=101)$, often $33.33 \%(\mathrm{~N}=77)$, this percentage is quite high regarding the fact that there is encouragement of Moodle usage. This usage is not mandatory in some cases, while sometimes usage $15.15 \%(\mathrm{~N}=35)$, and $7.79 \%(\mathrm{~N}=18)$ of students quietly rarely used it.

This result owes to the fact that there is encouragement of Moodle usage from the lectures to students where they get the basic knowledge from them to access the Moodle system.

\section{Hypothesis 1:}

There is a significant correlation between perceived ease of use of Moodle system and perceived usefulness among mass Communication students in Gulf universities.
Table (3) Correlation between perceived ease of use of Moodle system and perceived usefulness among mass Communication students in Gulf universities

\begin{tabular}{|l|l|l|}
\hline \multirow{2}{*}{} & \multicolumn{2}{|c|}{ perceived usefulness } \\
\cline { 2 - 3 } & Pearson $(\mathrm{R})$ & P Value \\
\cline { 2 - 3 } $\begin{array}{l}\text { perceived } \\
\text { ease of use }\end{array}$ & .519 & .000 \\
\hline $\mathrm{N}$ & 231 \\
\hline
\end{tabular}

Correlation is significant at the .01level (2 -tailed)

The study used a Pearson correlation coefficient to test the relationship between perceived ease of use of Moodle system and perceived usefulness among mass Communication students in Gulf universities. The results showed that there is a positive Correlation between the two variables $(\mathrm{R}=.519$, $\mathrm{N}=231$ and $\mathrm{P}=.000$ ). So, we can accept the hypothesis and conclude that There is a significant correlation between perceived ease of use of Moodle system and perceived usefulness among mass Communication students in Gulf universities.

\section{Hypothesis 2:}

There is a significant correlation between perceived ease of use of Moodle system and attitudes towards Moodle system usage among mass Communication students in Gulf universities.

Table (4) Correlation between perceived ease of use of Moodle system and attitudes towards Moodle system usage among mass Communication students in Gulf universities

\begin{tabular}{|l|l|l|}
\hline \multirow{4}{*}{$\begin{array}{l}\text { perceived ease } \\
\text { of use }\end{array}$} & \multicolumn{2}{|l|}{ Moodle system usage } \\
\cline { 2 - 3 } & Pearson (R) & P Value \\
\cline { 2 - 3 } $\mathrm{N}$ & .115 & .082 \\
\hline
\end{tabular}

Correlation is significant at the .01level (2 -tailed)

The study used a Pearson correlation coefficient to test the relationship between perceived ease of use of Moodle system and perceived usefulness among mass Communication students in Gulf universities. The results showed that there is no Correlation between the two variables $(\mathrm{R}=.115, \mathrm{~N}=231$ and $\mathrm{P}=.082$.) So, we cannot accept the hypothesis and conclude that there is no significant correlation between perceived ease of use of Moodle system and attitudes towards Moodle system usage among mass Communication students in Gulf universities.

\section{Hypothesis 3:}

There is a significant correlation between perceived usefulness and attitudes towards Moodle system usage among mass Communication students in Gulf universities. 
Table (5) Correlation between correlation between perceived usefulness and attitudes towards Moodle system usage among mass Communication students in Gulf universities

\begin{tabular}{|l|l|l|}
\hline \multirow{2}{*}{} & \multicolumn{2}{|l|}{ Moodle system usage } \\
\cline { 2 - 3 } perceived & $\begin{array}{l}\text { Pearson } \\
(\mathrm{R})\end{array}$ & P Value \\
\cline { 2 - 3 } usefulness & .286 & .026 \\
\hline $\mathrm{N}$ & 231 \\
\hline
\end{tabular}

Correlation is significant at the .01level (2 -tailed)

The study used a Pearson correlation coefficient to test the relationship between correlation between perceived usefulness and attitudes towards Moodle system usage among mass Communication students in Gulf universities. The results showed that there is a Correlation between the two variables $(\mathrm{R}=.286, \mathrm{~N}=231$ and $\mathrm{P}=.026)$. So, we can accept the hypothesis and conclude that there is a significant correlation between correlation between perceived usefulness and attitudes towards Moodle system usage among mass Communication students in Gulf universities.

\section{Hypothesis 4:}

There is a significant correlation between perceived usefulness of use of Moodle system and behavioral intention among mass Communication students in Gulf universities.

Table (6) Correlation between correlation between perceived usefulness of use of Moodle system and behavioral intention among mass Communication students in Gulf universities

\begin{tabular}{|l|l|l|}
\hline \multirow{2}{*}{$\begin{array}{l}\text { perceived } \\
\text { of use }\end{array}$} & \multicolumn{2}{|l|}{ behavioral intention } \\
\cline { 2 - 3 } ofe & Pearson (R) & P Value \\
\cline { 2 - 3 } $\mathrm{N}$ & .059 & .650 \\
\hline & 231 \\
\hline
\end{tabular}

Correlation is significant at the .01level (2 -tailed)

The study used a Pearson correlation coefficient to test the relationship between perceived usefulness of use of Moodle system and behavioral intention among mass Communication students in Gulf universities. The results showed that there is no Correlation between the two variables $(\mathrm{R}=.059, \mathrm{~N}=231$ and $\mathrm{P}=.650)$. So, we cannot accept the hypothesis and conclude that there is no significant correlation between perceived usefulness of use of Moodle system and behavioral intention among mass Communication students in Gulf universities.

\section{Hypothesis 5:}

There is a significant correlation between perceived usefulness of use of Moodle system and Self- efficiency mass Communication students in Gulf universities.
Table (7) Correlation between correlation between perceived usefulness of use of Moodle system and Selfefficiency mass Communication students in Gulf universities.

\begin{tabular}{|l|l|l|}
\hline \multirow{2}{*}{\begin{tabular}{l}
\multirow{2}{*}{$\begin{array}{l}\text { perceived } \\
\text { ease of use }\end{array}$} \\
\cline { 2 - 3 }
\end{tabular}} & \multicolumn{2}{|l|}{ Self- efficiency } \\
\cline { 2 - 3 } & Pearson (R) & P Value \\
\hline $\mathrm{N}$ & 231 & .750 \\
\hline
\end{tabular}

Correlation is significant at the .01level (2 -tailed)

The study used a Pearson correlation coefficient to test the relationship between perceived usefulness of use of Moodle system and Self- efficiency mass Communication students in Gulf universities. The results showed that there is no Correlation between the two variables $(\mathrm{R}=.041, \mathrm{~N}=231$ and $\mathrm{P}=$.759). So, we cannot accept the hypothesis and conclude that there is no significant correlation between perceived usefulness of use of Moodle system and Self- efficiency mass Communication students in Gulf universities.

\section{Hypothesis 6:}

There is a significant correlation between Subjective Norms and attitudes towards Moodle system usage among mass Communication students in Gulf universities.

Table (8) Correlation between correlation between Subjective Norms and attitudes towards Moodle system usage among mass Communication students in Gulf universities

\begin{tabular}{|l|l|l|}
\hline \multirow{2}{*}{$\begin{array}{l}\text { Subjective } \\
\text { Norms }\end{array}$} & \multicolumn{2}{|l|}{ Moodle system usage } \\
\cline { 2 - 3 } & Pearson (R) & P Value \\
\cline { 2 - 3 } $\mathrm{N}$ & .736 & .000 \\
\hline
\end{tabular}

Correlation is significant at the .01level (2 -tailed)

The study used a Pearson correlation coefficient to test the relationship between correlation between Subjective Norms and attitudes towards Moodle system usage among mass Communication students in Gulf universities. The results showed that there is a Correlation between the two variables $(\mathrm{R}=.286, \mathrm{~N}=231$ and $\mathrm{P}=.026)$. So, we can accept the hypothesis and conclude that there is a significant correlation between correlation between Subjective Norms and attitudes towards Moodle system usage among mass Communication students in Gulf universities.

\section{DISCUSSION AND CONCLUSION}

Moodle has become ubiquitous and has a part of university life. consequently, students are spending fundamental part of their time on Moodle system in all universities all around the world. University students are considered the largest users of Moodle system. Despite a ubiquitous of this system, there is a dearth of studies in Gulf universities on how Moodle system affects the students' performance and academic achievement by changing the way students interact. 
The study addressed this issue by examining the nature of Moodle usage and all factors affected it the frequency of this usage and addressed the purposes why students use Moodle system. The researcher used survey method to collect the data from Gulf universities that applied this system.

The study analyzed the main factors of the theory of Reasoned Action (TRA) and the theory of Planned behavior (TPB) applying to a sample of 231 students from Gulf universities who used the Moodle system in these universities.

The results contribute to understand - to some extent- the usage of Moodle system in Gulf universities in some fields such as:

- The purposes of using Moodle system: The results revealed that the students used the Moodle system for many purposes such as: doing assignments, to check upcoming events, downloading the course materials and to participate in discussion with my instructors. The study agreed with (Carolina Costa \& et al.2012) who concluded that Moodle system provides interactivity also between instructor and students by using interactive tools to facilitate the good communication such as: Chats, assignments submission, Forums, online news and announcements, files downloads grading /marks, and online quiz.

- Perceived ease of Moodle use: The results revealed that the most impactful perceived ease of use factors: easy usage, flexibility and interaction. The study agreed with (Prashant Bargea, B.R. Londhe, 2014) who concluded that Moodle systems allows availability, less technical difficulties, continuous progress, flexibility, and most accepted by top universities all over the world.

- Perceived usefulness: The results revealed that the most impactful perceived usefulness factors: allow instructors to submit quizzes with model answers, allow students to get information faster, improve the scientific performance of students and enhance learning effectiveness. The results contradict the study of (Sacide Güzin Mazman Akar,2019), whose study revealed that the innovativeness is influenced by the technology acceptance of teachers and perceived ease of use, perceived usefulness and subjective norms determine the behavioral intentions, not the Moodle only.

Behavioral Control: The results revealed that the most impactful behavioral control factors: Using Moodle system would be entirely within the control of students, ability, resources and knowledge to use and using without help. The results contradict the study of (Hye Jeong Kim\&et al,2019) who confirmed the students must have good skills to perform the academic assignments.

- Subjective Norms: The results revealed that the most impactful Subjective Norms factors: the university supports the Moodle system usage; the colleagues facilitate the usage among themselves and the instructors think that their students use Moodle system. the instructors must take part in developing teaching and learning by using Moodle system. The results agree with the study of (Valentino van de Heyde\& André Siebrits, 2019) who confirmed the instructors must take part in developing teaching and learning by using Moodle system.

- Moodle system adoption: The results revealed that the most Moodle system adoption factors: The instructors support the use of Moodle system, the students plan to use Moodle system in the future, the students feel pressure from my instructors to adopt Moodle system, they have basic knowledge of Moodle system tools to use it in their courses.
The results contradict the study of (Valentino van de Heyde\& André Siebrits, 2019) who confirmed that the students must be core focus in the adoption of technology and the instructors must take part in developing teaching and learning by using Moodle system.

Technical support: The results revealed that the most Moodle system adoption factors: When the students face any difficulty in Moodle system usage, they get rapidly assistance, the university offers technicians to provide assistance and when they face any problem in Moodle system usage, they know where to get assistance. The results agree the study of (Prashant Bargea, B.R. Londhe, 2014) who confirmed that Moodle system has less technical difficulties. Moodle Self- efficiency: The results revealed that the most Moodle Self- efficiency factors: The students can use Moodle system even though there was no assistant instruction tool with it, Moodle system helps me improve my learning quality, Moodle system usage is important. The results agree the study of (Gabriela Carmen Oproiu, 2015) who confirmed that Moodle is facilitating the learning method.

Perceived satisfaction: The results revealed that the most perceived satisfaction factors: the students satisfied with their experience using Moodle system, Moodle system processes (uploading or downloading), Moodle system effectiveness, Moodle system efficiency. The results agree the study of (Zurinah Suradi\& et al 2018) who confirmed that the students indicated Moodle system effectiveness and efficiency made them more satisfied with the Moodle system available at universities.

Social influence: The results revealed that the most Social influence factors: The instructors want the students to use Moodle system frequently, they support them to use Moodle system and their colleagues want them to use Moodle system frequently. The results agree the study of (Gabriela Carmen Oproiu, 2015) who confirmed that Moodle contributes in collaborating with peers in doing homework.

Communication: The results revealed that the most Communication factors: Moodle system allows exchange of ideas and information between instructors and students, allows instructors to add posts and send emails, Moodle system allows students to upload assignments and allows instructors to evaluate students' evaluation and provide feedback with grade. The results agree the study of(Carolina Costa \& et al.2012) who confirmed that the Moodle system provides interactivity also between instructor and students by using interactive tools to facilitate the good communication such as: Chats, assignments submission, Forums, online news and announcements, files downloads grading /marks, and online quiz.

behavioral intention: The results revealed that the most behavioral intention factors: the students intend to use Moodle system constantly in the future, If the Moodle system is easy, they will use it as much as possible and If the Moodle system is easy, they will download/upload course materials. The results agree the study of (Deepak KC,2017) who confirmed that the Moodle facilitate in introducing the course content, course specification and course feedback. 
Attitudes towards Moodle use: The results revealed that the Attitudes towards Moodle use: I fell positively about Moodle system, Moodle system usage is more interesting than the traditional method, Using Moodle system improves students' creativity and the students received course assignments evaluation in a timely manner. The results agree the study of (Gabriela Carmen Oproiu, 2015) who confirmed that Moodle facilitates the learning method, facilitate the self-assignments and online assessment is more objective than traditional method "Face-to- Face" learning.

- Testing Hypotheses: The results indicated that there is a significant correlation between perceived ease of use of Moodle system and perceived usefulness among mass Communication students in Gulf universities, the results also indicated that there is a significant correlation between perceived usefulness and attitudes towards Moodle system usage among mass Communication students in Gulf universities(Teo, Timothy \& et al, 2019) and there is a significant correlation between correlation between Subjective Norms and attitudes towards Moodle system usage among mass Communication students in Gulf universities . Meanwhile the results indicated that there is no significant correlation between perceived ease of use of Moodle system and attitudes towards Moodle system usage among mass Communication students in Gulf universities, also indicated that there is no significant correlation between perceived usefulness of use of Moodle system and behavioral intention among mass Communication students in Gulf universities and there is no significant correlation between perceived usefulness of use of Moodle system and Selfefficiency mass Communication students in Gulf universities. The results agree the study of (Deepak KC,2017) who confirmed that the Moodle facilitate in introducing the course content, course specification and course feedback. The results contradict the study of (Olayemi Abdullateef Aliyu\&et al,2019) who confirmed that Behavioral intentions has a significant influence of Moodle usage.

\section{RECOMMENDATIONS}

The study is suggested to investigate academic concerns and needs to develop the usage of Moodle in Arabian and Gulf universities.

The study is suggested to encourage students to use Moodle system where they felt is an additional work besides the routine tasks.

- The study is suggested to perform studies about obstacles that face E- learning in the Academic environment to enhance the success of the teaching and learning process.

\section{REFERENCES}

1. Nada I. Alhothli. (2015). Investigating the Impact of Using Moodle as an E-Learning Tool for Students in an English Language Institute, Un-Published Master Thesis, The University of Montana, the Graduate School at Scholar Works, p21.

2. Reham Kh. Aljeeran, M.A. (2016). The Role of Socio-Cultural Factors in Faculty Members' Acceptance of Moodle at GUST, Un-Published PHD Dissertation, The Ohio State University, the Graduate School, p 42.

3. Muhammad-Bashir Owolabi Yusuf; Onikosi-Alliyu Saidat Oluwatoyin. (2019). User Acceptance of Crash Helmet by Motorcyclists in Malaysia: An Empirical Analysis, Studia Universitatis "Vasile Goldis" Arad. Economics Series, Vol 29 Issue 1, p41.
4. Quynh Anh Nguyen; Luc Hens; Charlotte MacAlister ; Lester Johnson ; Boripat Lebel ; Sinh Bach Tan ; Hung Manh Nguyen ; The Ninh Nguyen ; Louis Lebel .(2019). Theory of Reasoned Action as a Framework for Communicating Climate Risk: A Case Study of Schoolchildren in the Mekong Delta in Vietnam, Sustainability, Vol 10, p 3.

5. Ramasami Alagrisamy; Lawrence Arokiasamy. (2019). A Study on Young Female Adults' Intention and Adoption of Emergency Contraceptive Pill in Rural Malaysia, Global Business and Management Research: An International Journal, Vol. 11, No. 1, p 507.

6. Abdulwahab Ali Almarazroi; Eltahir Kabbar ; Muawya Naser Haifeng Shen .(2018). Gender Effect on Cloud Computing Services Adoption by University Students: Case Study of Saudi Arabia, International Journal of Innovation; Sao Paulo Vol. 7, Issue. 1, (Jan-Apr), pp 155-177.

7. Timothy Teo; Mingming Zhou; Jan Noyes. (2016). Teachers and technology: development of an extended theory of planned behavior, Educational Technology Research and Development, Vol 64, No3, p3.

8. Odoyo Collins Otieno; Samuel Liyala; Benson Charles Odongo;Silvance Abeka.(2016). Theory of Reasoned Action as an Underpinning to Technological Innovation Adoption Studies, World Journal of Computer Application and Technology, Vol4, Issue1, p5.

9. Abdul Ghafarmansor M. M. Mohamad; Syedzulkarnain Syed Idrus; Amani Ali Elmetwely Ali Ibrahim. (2018). Model of Behavioral Attention towards Using ICT in Universities in Libya, Malaysian Journal of Communication, Vol 34, Issue 2, p96.

10. Neeraj Gangwal; and Veena Bansa. (2016). Application of Decomposed Theory of Planned Behavior for M-commerce Adoption in India, In Proceedings of the 18th International Conference on Enterprise Information Systems (ICEIS), Vol 2, p 358.

11. Sirois, F. M. (2015). A self-regulation resource model of self-compassion and health behavior intentions in emerging adults. Preventive medicine reports, 2, p220.

12. Aboelmaged, M., \& Gebba, T. R. (2013). Mobile banking adoption: An examination of technology acceptance model and theory of planned behavior. International Journal of Business Research and Development (IJBRD), Vol2, Issue1, p 39.

13. Dharmendra Chourishi; Chanchal Kumar Buttan; Abhishek Chaurasia; Anita Soni.(2011). Effective E-Learning through Moodle, International Journal of Advance Technology \& Engineering Research (IJATER), Vol. 1, Issue 1, November, pp34-38.

14. Carolina Costaa; Helena Alvelosa,; Leonor Teixeiraa.(2012). The use of Moodle e-learning platform: a study in a Portuguese University, CENTERIS - Conference on ENTERprise Information Systems, pp334-343.

15. Prashant Bargea; B.R. Londhe.(2014). From Teaching, Learning to Assessment: MOODLE experience at B'School in India, Symbiosis Institute of Management Studies Annual Research Conference (SIMSARC13), Procedia Economics and Finance 11, pp 857 - 865.

16. Gabriela Carmen Oproiu. (2015). A Study about Using E-learning Platform (Moodle) in University Teaching Process, The 6th International Conference Edu World 2014 "Education Facing Contemporary World Issues", 7th - 9th November 2014, Procedia Social and Behavioral Sciences 180 ,pp $426-432$.

17. Deepak KC. (2017). Evaluation of Moodle Features at Kajaani University of Applied Sciences - Case Study, 2nd International Conference on Computer Science and Computational Intelligence 2017, ICCSCI, 13-14 October 2017, Bali, Indonesia, pp121-128.

18. Nurkhamimi Zainuddin; Rozhan Idrus; Ahmad Farid Mohd Jamal. (2016). "Moodle as an ODL teaching tool: A Perspective of Students and Academics" The Electronic Journal of e-Learning, Vol 14 Issue 4, pp282-290.

19. Irina Rymanova; Nikolai Baryshnikova; Anna Grishaeva. (2015). E-course Based on the LMS Moodle for English Language Teaching: Development and Implementation of Results, XV International Conference "Linguistic and Cultural Studies: Traditions and Innovations", LKTI 2015, 9-11 November 2015, Tomsk, Russia, pp 236-240.

20. Teo, Timothy; Zhou, Mingming ; Fan, Andy Chun Wai ; Huang, Fang. (2019). Factors that Influence University Students' Intention to use Moodle: a Study in Macau, Educational Technology, Research and Development; New York Vol. 67, Issue 3, June), pp 749-766. 
21. Olayemi Abdullateef Aliyu, Chris Arasanmi; Samuel Ekundayo.(2019). Do demographic characteristics moderate the acceptance and use of the Moodle learning system among business students? International Journal of Education and Development using Information and Communication Technology (IJEDICT), Vol. 15, Issue 1, pp. 179-192

22. Valentino van de Heyde; André Siebrits.(2019).The ecosystem o e-learning model for Authors: higher education, South African Journal of Science, Vol 115, No 5/6May/June,pp78-83 23. Salloum, Said A ; Al-Emran, Mostafa ; Shaalan, Khaled ; Tarhini, Ali.(2019). Factors affecting the E-learning acceptance: A case study from UAE, Education and Information Technologies; Vol. 24, Iss. 1, (Jan).

24. Sacide Güzin Mazman Akar. (2019). Does it matter being innovative: Teachers' technology acceptance,Education and Information Technologies, Vol 4, pp1-18.

25. Hye Jeong Kim;Ah Jeong Hong; Hae-Deok Song.(2019). The roles of academic engagement and digital readiness in students' achievements in university e-learning environments, International Journal of Educational Technology in Higher Education, Vol 16, Issue 21,pp 1-18.

26. Zurinah Suradi, Jawaher Awadh Mohammed Baqwir, Noor Haslina Yusoff. (2018). FactorsAffecting the Use of Moodle System among Students in Dhofar University, Proceedings of 130th The IRES International Conference, Taipei, Taiwan, 26th -27th July, p1.

27. Ibrahim Zalah. (2018). Factors That Influence Saudi Secondary Teachers' Acceptance and Use of E-Learning Technologies, Un-published PHD Dissertation, University of Brighton, p98.

28. Naif M. Malayali. (2018). Saudi Arabian Students' Attitudes toward E-Learning in Select Pennsylvania Universities, Un-published PHD Dissertation, Indiana University of Pennsylvania, School of Graduate Studies and Research, p38.

29. Ahmed Al-Azawei; Patrick Parslow; Karsten Lundqvist. (2017). Investigating the effect of learning styles in a blended e-learning system: An extension of the technology acceptance model (TAM), Australasian Journal of Educational Technology, Vol 33, Issue 2, p5.

30. Irene Govender; Sakhile Khumalo. (2014). Reasoned Action Analysis Theory as a Vehicle to Explore Female Students' Intention to Major in Information Systems, J Communication, Vol 5, Issue1, p39.

\section{AUTHORS PROFILE}

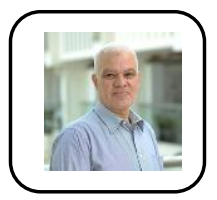

Dr. Abdulsadek Hassan. Associate Professor College of Arts \& Science - Mass Communications \& Public Relations Dept. - PHD degree in Mass Communication, (2006), Journalism Department, Faculty of Mass Communication, Cairo University, Egypt. His main researches include New media, Public Relations, New Technology and he has published 40 articles in Mass Communication and Public Relations. He is a member in many scientific journals advisory boards and a reviewer as well.

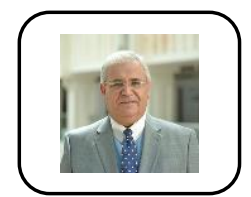

Prof. Ismail Noori Mseer- Acting Dean / College of Arts \& Science - Arabic \& General Studies Dept. His main researches include Critical thinking in A Transformed World, Historical Research aand Escaping Patterns. Orientalism on Cultural Dispute. He is a member in many scientific journals advisory boards and a reviewer as well.

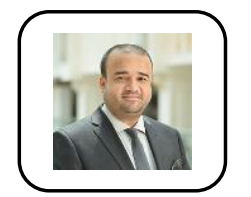

Dr Allam Hamdan, Chairperson of Accounting and Economics Department since 2013, Professor / Acting Dean Accounting \& Economics Dept. College of Business \& Finance. Has published more than 60 papers in regional and international journals. Obtained his PhD in Accounting from Arab Academy of Banking and Financial Sciences, Amman, Jordan. Also awarded the International Excellence Award in Islamic Marketing. Has expertise in building research methodology and models and has a good command in statistical analysis and econometrics while showing Interest in applying empirical studies in accounting and finance. He is a member in many scientific journals advisory boards and a reviewer as well.

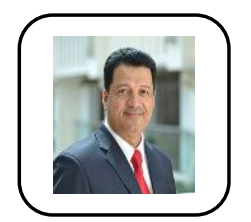

Dr. Muneer Mohamed Al Mubarak. Associate Professor /Acting VP for Admin \& Finance/ Acting Dean of Student Affairs -. He received his Ph.D. in Business \& Economic Studies (Marketing), from University of Leeds, UK, early 2010. Dr. Muneer's expertise is in strategic management, marketing management, relationship marketing and loyalty. He contributed well in senior management, strategic planning with over 30 years of experience in business, education and corporate training in areas such as Leadership \& Strategic Management, Relationship Marketing and loyalty.

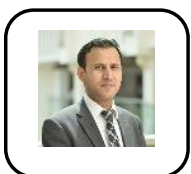

Dr Adel M. Sarea.Associate Professor / College of Business \& Finance - Accounting \& Economics Dept. He has published two books, editor of three books, published four book chapters and more than 50 papers in internationally renowned journals and he serves on the editorial team of several international journals published by Elsevier Publishing, Emerald Group Publishing, Inderscience Publishers Ltd and IGI Global Publisher, USA. Awarded the Best Paper Award in 2014, Emerald Publishing Group, Literati Network Awards for Excellence. 